\title{
The Effects of Hypophysectomy upon Dna Synthesis in Rat Oral Epithelium
}

Olivia Ramirez

Loyola University Chicago

Follow this and additional works at: https://ecommons.luc.edu/luc_theses

Part of the Dentistry Commons

\section{Recommended Citation}

Ramirez, Olivia, "The Effects of Hypophysectomy upon Dna Synthesis in Rat Oral Epithelium" (1976). Master's Theses. 2867.

https://ecommons.luc.edu/luc_theses/2867

This Thesis is brought to you for free and open access by the Theses and Dissertations at Loyola eCommons. It has been accepted for inclusion in Master's Theses by an authorized administrator of Loyola eCommons. For more information, please contact ecommons@luc.edu. (c) $($ ) $\Theta \Theta$

This work is licensed under a Creative Commons Attribution-Noncommercial-No Derivative Works 3.0 License. Copyright @ 1976 Olivia Ramirez 
THE EFFECTS OF HYPOPHYSECTOMY UPON DNA SYNTHESIS

IN RAT ORAL EPITHELIUM

by

Olivia Ramirez

A Thesis Submitted to the Faculty of the Graduate School of Loyola University of Chicago in Partial Fulfillment of the Requirements for the Degree of

Master of Science

June

1976

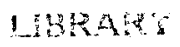

LOYOLA UNIVERSTY MEDICAL CENTER 
I dedicate this thesis to

Dr. Patrick D. Toto 


\section{ACKNOWLEDGMENTS}

The author wishes to thank Dr. Patrick Toto for his advice and direction in planning this study and for his assistance in preparing the manuscript.

The author appreciates the review and revision of the manuscript performed by Dr. Anthony Gargiulo and sincerely thanks him for his services.

The author wishes to thank Dr. Donald Doemling for his careful and constructive review and correction of the manuscript. 


\section{BIOGRAPHY}

Olivia Ramirez was born on June 10, 1936, in Guadalajara, Mexico.

She graduated from Universidad de Guadalajara and received her Doctor of Dental Surgery degree in 1959.

From 1959 to 1972, she practiced general dentistry and taught French and Spanish.

In 1973, she attended a graduate program in Periodontics at the Universidad de Buenos Aires, Argentina, where she obtained a certificate in Periodontology.

Her graduate studies at Loyola University, Chicago, Illinois, began in January of 1974, in the Department of Periodontics. In May of 1975, she received a certificate of proficiency in Periodontology.

She was appointed Assistant Professor in the Department of Oral Pathology of Loyola University in the Summer of 1975, where she taught General and Oral Pathology. 
TABLE OF CONTENTS

Chapter

Page

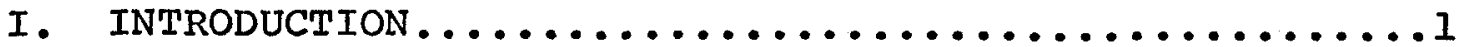

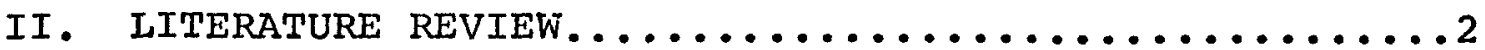

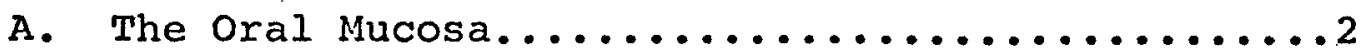

1. Squamous Epithelium Special

Morphology.......................... 4

2. Principal Products of

Keratinizing Epithelium................

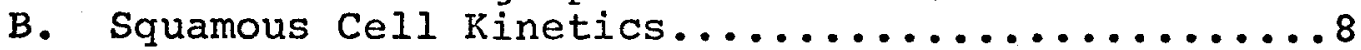

1. Use of Tritiated Thymidine Label...........8

2. Tritiated Thymidine Pathways of

Incorporation and Degradation............9

3. Tritiated Thymidine Labeling

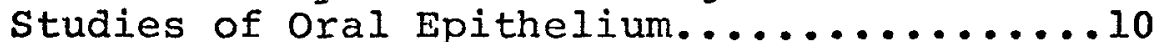

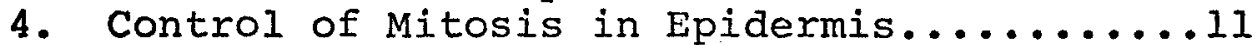

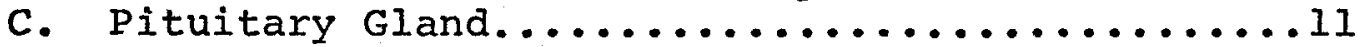

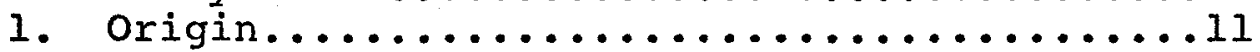

2. Composition of the Hypophysis............12

D. Hypothalamic Control of the

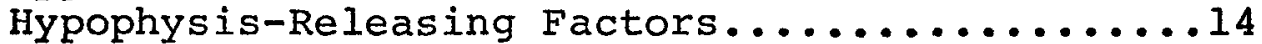

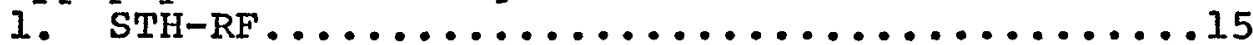

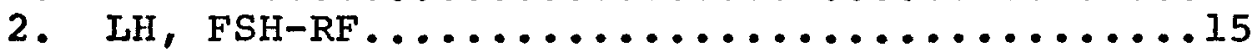

3. CRF ............................... 15

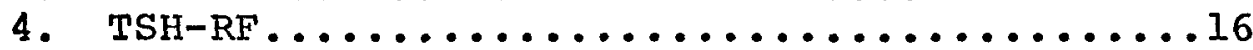

E. Biologic Activity of Pituitary Trophic

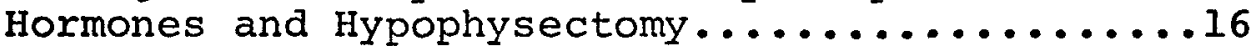

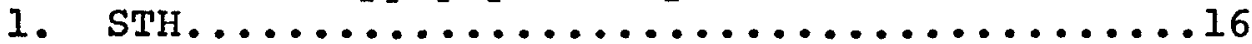

2. Prolactin......................... 17

3. FSH............................. 17

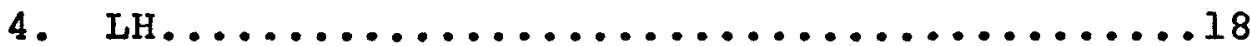

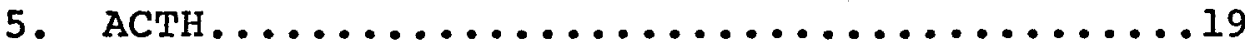

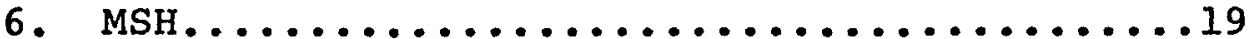

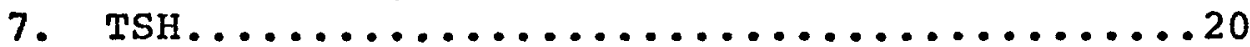

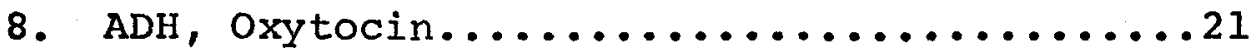

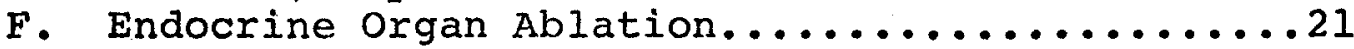

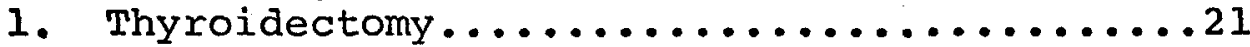

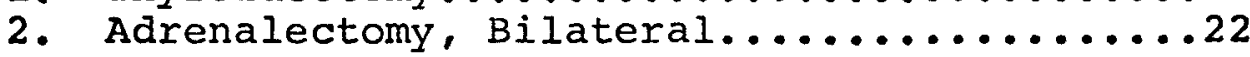

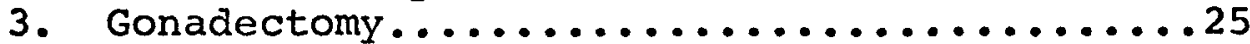

G. Effects of Hypophysectomy on Oral

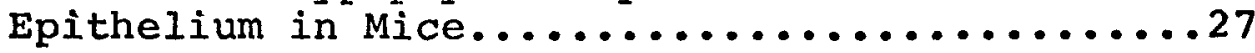


TABLE OF CONTENTS continued

Chapter

Page

H. Hormone Control of Nucleoprotein

Metabolism.........................27

III. MATERIAL AND METHODS...........................

A. Weight..............................

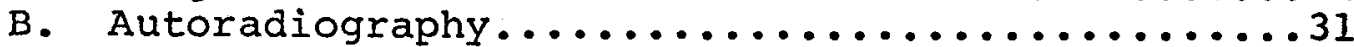

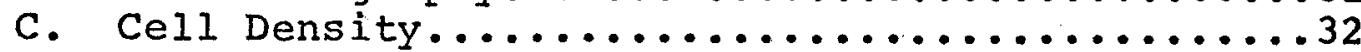

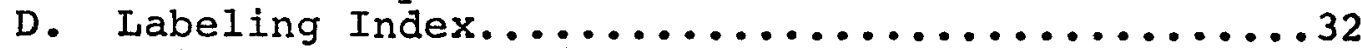

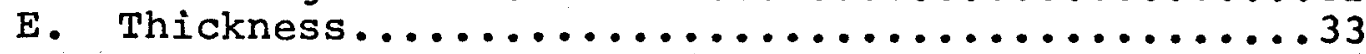

IV. RESULTS..............................

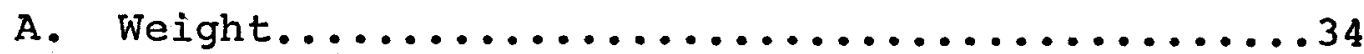

B. Epithelial Morphology .......................

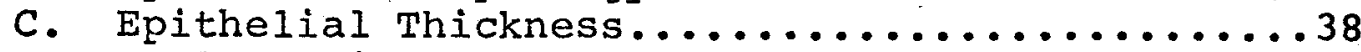

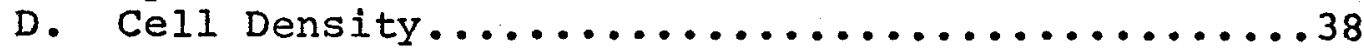

E. Labeling Index.........................

V. DISCUSSION........................43

A. Weight.........................43

B. Epithelial Morphology ......................

C. Epithelial Thickness..................43

D. Cell Density ......................... 44

E. Labeling Index......................

VI. SUMMARY AND CONCLUSIONS................. 50

VII. BIBIIOGRAPHY........................ 51 


\section{LIST OF TABLES}

Table

Page

I. HORMONE-SECRETING CELLS OF THE

ANTERIOR PITUITARY OF THE RAT..............13

II. ADRENALECTOMIZED MICE AND

HYPOPHYSECTOMIZED MICE PERCENTAGE

OF LABELED CELIS IN EPITHELIUM OF

INTERDENTAL PAPILLA SECTIONS AT

VARIOUS TIME INTERVALS.................28

III-1. WEIGHTS OF CONTROL AND

HYPOPHYSECTOMIZED RATS 50-DAYS-OLD...................

III-2. THICKNESS OF PALATAL SQUAMOUS

EPITHELIUM IN 50-DAY-OLD FEMALE

RATS 5 DAYS FOLLOWING HYPOPHYSECTOMY.............. 39

III-3. THE CELI DENSITY OF SQUAMOUS CELLS

IN THE PALATE OF CONTROL AND

HYPOPHYSECTOMIZED RATS 55-DAYS-OLD...........40

III-4. TRITIATED THYMIDINE LABELING FREQUENCY

OF THE PALATAL SQUAMOUS EPITHELIUM IN

CONTROL AND HYPOPHYSECTOMIZED RATS

55-DAYS-OLD........................42

vii 


\section{IIST OF FIGURES}

Figure

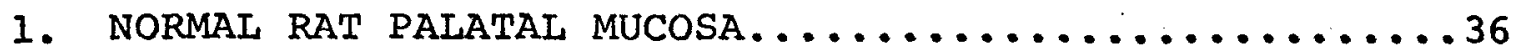

2. HYPOPHYSECTOMIZED RAT PALATAL MUCOSA................... 


\section{CHAPTER I}

\section{INTRODUCTION}

The hypophysectomized rat fails to gain weight. This results from the profound metabolic effect resulting from loss of hormones from the pituitary and its target organs. There is a loss of somatotrophic hormone, adrenocorticotrophic hormone, thyroid stimulating hormone, follicle stimulating hormone, luteinizing hormone, prolactin, vasopressin and oxytocin. There results a depression of blucose and aminoacids and fat metabolism.

This depression in metabolic activity and loss of growth has a profound effect upon the growth and renewal of stratified squamous epithelium in the palate of rats. Hypophysectomized rats were treated with tritiated thymidine to label the oral squamous cells during the synthesis of desoxyribonucleic acid. The frequency of labeled cells was counted and found to be depressed. The thickness of the epithelium and cell density were reduced. The morphology appears to maintain its normal characteristics indicating continued differentiation. The oral epithelium responds to hypophysectomy by reduced metabolic activity in new cell formation with a net loss of cells. 


\section{CHAPTER II}

\section{LITERATURE REVIEW}

A. The Oral Mucosa

General Features: The oral mucosa of the palate of the rat has the general morphology found in all vertebrates. It is composed of stratified squamous epithelium and supporting connective tissues. The epithelium is separated from the connective tissue by a basement membrane.

The stratified squamous epithelium is divided into two functional compartments: generative and differentiative. The generative compartment includes the basal cell layer and the lower spinous layer. The differentiative layer includes the upper spinous, the granular layer, and the stratum corneum. Meyer and Gerson in 1964 reported that in the palate of the rat the cell layers of the epithelium average $133 \mu$ thick.

The connective tissue immediately in contact with the basal cell layer is the lamina propria. This layer contains lymphatics, capillaries, fibroblasts, histiocytes, mast cells, reticular fibers, sensory nerve endings, and ground substance.

Gersh and Catchpole in 1960 reported that the ground substance is negatively charged and contains hyaluronic acid, chondroitin sulfate and keratan sulphate. Many cations 
including $\mathrm{Na}^{+}, \mathrm{Mg}^{+}, \mathrm{Ca}^{++}$, and $\mathrm{K}^{+}$are bound to the ground substance. The basement membrane is composed of a carbohydrateprotein complex produced by the basal cells. They synthesize such complexes which come into contact with the ground substance produced by the fibroblasts in the lamina propria. It is probable that both the basal cells and fibroblasts contribute to the basement membrane.

Palade and Farquar in 1965 showed that the reticular fibers in the basement membrane are composed of collagen fibers which form perpendicular loops and longitudinal complexes, and they serve together with the protein-carbohydrate complex to attach the epithelium to the connective tissues. Gersh and Catchpole in 1960, Joseph, Engel, and Catchpole in 1954, and Catchpole, Joseph, and Engel in 1956, reported that the ground substance with fibers contains water and together with electrolytes from the blood they form a colloid which has a net negative charge at the normal $\mathrm{pH}$ of 7.4. The isoelectric point lies between $\mathrm{pH} 7.4$ and $\mathrm{pH} 5$. The basement membrane not only attaches epithelium to connective tissue but serves as a selective membrane permeable to the transudate emerging from the capillaries containing essential nutrients needed for generative and differentiative functions of the epithelium. The pressure gradient between the epithelium and lamina propria favors passage of water and solutes through the basement membrane into the overlying 
epithelium.

1. Squamous Epithelium Special Morphology

Meyer and Gerson (1964) have reported that the basal

cells of the palate have an angular shape compared to buccal epithelium. The cytoplasm contains tonofibrils and lysosomes. The tonofibrils of the basal cells at the basement membrane interface are organized with the plasma membrane to form an attachment plaque or hemidesmosome which forms attachment with reticular fibers in the basement membrane. This attachment plaque also serves to bind the epithelium to the lamina propria. The nuclei of the basal cells function by mitotic division for generative purposes and RNA synthesis as needed to produce the proteins for cell differentiation.

Meyer and Squier (1971) stated that in the stratum spinosum are large polygonal cells with intercellular bridge connections. Such bridges correspond to the tonofibrils attached to thickened electron dense plasma membrane forming attachment plaques and together with adjacent cells form the desmosome. This serves to attach all spinous cells together. The cytoplasm contains endoplasmic reticulum, mitochondria, lysosomes, tonofibrils, carbohydrate-protein complexes, granules of glycogen and, in the upper layers, keratohyaline granules. The nuclei in the lower spinous layer function to some extent by mitotic division and the synthesis 
of RNA needed for protein synthesis. Henry in 1952 reported that the basal cells contribute between $2 \%$ - $35 \%$ of the generative population of cells in the rabbit. The uppermost layer of the stratum spinosum of the palate begins to flatten and form electron dense keratohyaline granules which are bound externally by RNA and also appear to bind together the intracellular tonofibrils in the upper stratum granulosum layer. The nuclei become pyknotic and there is a reduction in mitochondria. In the stratum corneum, there is loss of desmosomes allowing the cells to separate.

Plakova, Waterhouse, and Meyer in 1970 reported that the stratum corneum loses the attachment of tonofibrils reducing the number of desmosomes. The nucleus and organelles are lost. There is a loss of keratohyaline in RNA, mitochondria and endoplasmic reticulum. The very surface cells contain intercellular fibrils and acid phosphatase positive granules.

The lower spinous cell layers contain glycogen while little or none is present in the basal cells. As the spinous layers of the palate mature and enter the upper layers the glycogen is lost.

2. Principal Products of Keratinizing Epithelium Weslocki, Fawcett, and Dempsey (1951), Weinman et al. (1959), and Meyer and Gerson (1964) reported that glycogen is one of the products of differentiating cells in 
non-keratinized tissue such as that in the human vagina and that lining oral buccal epithelium, soft palate, and the ventral surface of tongue. In alveolar mucosa glycogen may be seen above the deepest third of the prickle cell layer and some glycogen persists in the superficial cells.

In keratinizing oral epithelium in young rats, Sharav (1966) reported an accumulation of glycogen in the palatal epithelium but only in low concentration in the central layer of the prickle cell layer. Weiss, Weinman, and Meyer (1959) and Schroeder and Theilade (1966) described the presence of small amounts of glycogen in cells of the upper prickle cell and the granular layer of normal keratinized human gingiva.

Keratohyaline granules (KHG) are light visible and conspicuous in the granular layer of squamous epithelium named by waldeyer (1882). KHG found in esophageal and oral epithelium may originate in the nucleus (Posner, 1889). However, Jones (1965) and Perry (1967) shoed KHG to be synthesized by the RNA as intranuclear granules close to the nucleolus. They showed that histochemically, KHG contain protein bound to RNA in keratinizing epithelium. KHG are resistant to the action of urea and trypsin digestion in buffers of $\mathrm{pH} 2.9-8.6$ but are soluble in concentrated urea and buffer of $\mathrm{pH}$ 10.1. The KHG when dialysed reaggregate into granules similar in size, shape, histochemical staining 
and electron density as those seen in tissues in vitro. The KHG are electron dense bodies of variable size and shape. There is no evidence of a membrane.

Weinman, Meyer, and Medak (1960) showed that KHG of hard palate in mice are similar to those in skin epidermis and show intimate association with tonofibrils. KHG are thought to be the precursor substance which forms the binding matrix for tonofibrils of the process of keratinization to go to completion.

Barrington and Meyer (1969) reported that tonofilaments are the intracellular precursors of the protein keratin in the squamous epithelium. Keratin is the principal protein synthesized by the squamous epithelium; it is rich in sulfur because of the presence of cysteine. The tonofilaments may form in the absence of KHG layer. In the upper layers disintegration of cell organelles occurs with the tonofibrils remaining in the cells. This occurs in oral epithelia both with complete orthokeratinized and incomplete parakeratinized epithelia. There is dehydration of the upper squamous epithelia as keratinization proceeds.

The intercellular substances of oral squamous epithelium contain carbohydrates. Toto and Grandel (1966) showed histochemically, the presence of acid mucopolysacsharide intercellularly with aldehyde fuchsin and Alcian blue. Azure A extinction occurred at $\mathrm{pH}$ 2.5. Thonard and 
Sherp (1962) showed sulfation of intercellular cementing substances in oral squamous epithelium. Prendergast and Toto (1968) demonstrated the presence of blood group substances in human oral epithelium.

The plasma membrane of eukaryotic cells are proposed to be composed of lipid, protein, and polysaccharides. Singer and Nicolson (1971) proposed a bilaminar membrane of phospholipids containing protein within the membrane. The polysaccharides are attached to the proteins and extend out on the cell surface.

Moscona (1956) proposed that the molecular species and colloid charges on the cell surfaces allow the adjacent cells in tissues to identify one another as identical and to permit them to aggregate in a biologic system.

Fawcett in 1961 showed by electron microscopy the long protruding of cell surface molecules arising from the plasma membrane.

B. Squamous Cell Kinetics

1. Use of Tritiated Thymidine Label

The rat nucleus duplicates chromosomes during mitosis. There are 42 chromosomes in the diploid rat nucleus. The nucleus synthesizes desoxyribose nucleic acid periodically. Tritiated thymidine is radioactive; as the tritium atom disintegrates, it yields beta rays. When it is introduced into the rat by the intraperitoneal route, it is 
carried by the blood into the lamina propria and after passing through the basement membrane it enters the cellular layers via the intercellular spaces. It may then pass into the cell to enter the nucleus where it is incorporated in the synthesis of DNA producing a radioactive nucleus. 2. Tritiated Thymidine Pathways of Incorporation and Degradation

The incorporation pathway of tritiated thymidine into the squamous cell has been described by Grav and Smellie (1963). Tritiated thymidine (Tar) enters the cytoplasm and is phosphorylated. Thymidine kinase and ATP: thymidine $5^{l}$ phosphotransferase yields thymidine monophosphate (TMP). TMP kinase ATP: thymidine monophosphate phosphotransferase yields thymidine diphosphate (TDP). TDP kinase ATP: thymidine diphosphate phosphotransferase yields thymidine triphosphate (TTP). TTP and desocyribose nucleic acid polymerase transfers TMP to the DNA template and liberates the pyrophosphate.

The tritiated thymidine not used in the DNA synthesis undergoes degradation. It is reduced to dehydrothymine, beta-ureido-isobutyric acid, beta-amino isobutyric acid, and, finally, carbon dioxide, water, and ammonia.

All such degradation products are lost from the cell. Tritiated thymidine not used in DNA synthesis is excreted in the urine within one hour. 
Autoradiograms prepared from $5 \mu$ thick sections of the palate containing radioactive nuclei may be used to identify such nuclei. This method serves as a model to determine the frequency of cells in DNA synthesis. Moreover, as the cells enter mitosis, radioactive labeling of mitotic figures may be counted and, finally, the total number of cells initially seen in DNA synthesis is doubled in number in the interphase. Following the interphase the radioactive cells again enter mitosis. This allows for the determination of the cell cycle.

3. Tritiated Thymidine Labeling Studies of oral Epithelium

Toto and Dhawan (1966) and Toto and Ojha (1962) calculated the generation cell cycle in the mouse palatal mucosa as follows: $S_{1}$ (synthesis) 8 - 10 hours, $G_{2}$ (gap) 20 minutes, mitosis 40 minutes, and $G_{1}$ (gap - interphase) 96 hours. Meyer, Medak, and Weinmann (1960) estimated that all of the epithelium in the palate was replaced in 20 days. Furthermore, they counted mitotic figures in the mouse palate epithelium, compared this number to the total nucleated cell population, and determined that the index of mitosis is 2.5/1000, subject to diurnal variation. Joglekar (1964) determined the Tdr labeling index of the mouse gingival epithelium to be 98 and the doubling time to be 10 hours. Toto, Rubinstein, and Gargiulo (1975) determined the Tdr labeling 
index of the palate epithelium of young and old simonsen rats. They reported $4.5 \%$ in one month-old rats and $6.5 \%$ in 15 month-old rats, suggesting an increase in DNA synthesis in adult oral epithelium. Bullough and Lawrence (1961) reported that in nocturnal animals mitosis is higher in the day than at night.

4. Control of Mitosis in Epidermis

Bullough and Lawrence (1963) reported that the diurnal variation is determined by the circulating adrenaline which is low during sleep. They proposed the hypothesis that adrenaline combines with a substance produced by the squamous cell called chalone. The adrenaline-chalone complex inhibits mitosis. Hansen (1967) reported that adrenalectomized animals show increased mitotic activity as adrenaline levels fall. Bullough and Lawrence (1961) further showed that glucose can shorten the interphase period of the cell cycle bringing the cell into mitosis earlier. C. Pituitary Gland

1. Origin

The rat pituitary gland has its origin from primitive oral ectoderm (Rathkes pouch) and from the central nervous system (the infundibulum, an outpouching of the hypothalamus).

The Rathkes pouch differenciates into the pars intermedia by induction by the infundibulum while the remainder 
of the Rarhkes pouch differentiates into the pars distalis. The infundibulum differentiates into the pars nervosa and maintains continuity with the hypothalamus. A portal system of veins differentiates between the hypothalamus and the pars nervosa. The portal veins receive many nerve termini in their walls from the brain.

2. Composition of the Hypophysis

a. The pars intermedia and distalic comprise the adenohypophysis. The cells of the pars intermedia are polygonal and stain basophilic. The pars distalis contains cords of epithelial cells which are differentiated into acidophilic granules-containing and those containing basophilic granules. Also, cells with few granules fail to take a stain and are called chromophobes. Such cells are thought to be either agranular resting cells or the degranulated precursors of acidophils or basophils.

The rat pars distalis contains two kinds of acidophils: the somatotrophs which secrete growth hormone and the lactotrophs which secrete prolactin. The basophils are gonadotrophic cells and secrete follicle stimulating hormone (FSH), luteinizing hormone $(\mathrm{LH})$, thyroid stimulating hormone (TSH), and adrenocortical stimulating hormone (ACTH). The FHS, LH, and TSH are periodic acid Schiff positive and contain carbohydrate as glycoproteins and mucopolysaccharides. On the other hand, STH and lactotrophs are 
TABLE I

HORMONE-SECRETING CELIS OF THE ANTERIOR PITUITARY OF THE RAT

\begin{tabular}{|c|c|c|c|c|c|}
\hline Cell Type & $\begin{array}{r}\text { Secreted } \\
\text { Hormone } \\
\end{array}$ & $\begin{array}{c}\text { Cell } \\
\text { Staining } \\
\end{array}$ & $\begin{array}{c}\text { Orange } \\
\mathrm{G} \\
\end{array}$ & PAS & $\begin{array}{l}\text { Granule } \\
\text { Size mu }\end{array}$ \\
\hline Somatotrophs & Growth & Acidophil & + & - & 350 \\
\hline Lactotrophs & Prolactin & Acidophil & + & - & 600 \\
\hline Corticotrophs & АCTH & Chromophobe & - & - & 100 \\
\hline FSH Gonadotrophs & FSH & Basophil & - & + & 200 \\
\hline IH Gonadotrophs & $\mathrm{LH}$ & Basophil & - & + & 200 \\
\hline Thyrotrophs & TSH & Basophil & - & + & 140 \\
\hline Melaninotroph & $\mathrm{MSH}$ & Basophil & - & + & 150 \\
\hline
\end{tabular}

Modified from Ganong, W.S., Review of Medical Physiology, New York: Springen Verlage, 1969. 
polypeptides.

b. The pars nervosa, neurohypophysis, is composed of branching cells called pituicytes and a thick network of unmyelinated nerve fibers. They form a network in the vicinity of the venous portal system but do not form synapses with the pituicytes. Neurosecretory material from the hypothalamic nuclei move along the axons of the hypothalamic hypophyseal tract into the neural lobe and are stored, modified, discharged, and released into general circulation. D. Hypothalamic Control of the Hypophysis-Releasing

\section{Factors}

Hypothalamic control of the adenohypophyseal secretion is regulated by releasing factors RF. CRF corticotrophic hormone releasing factor, SRF somatotrophic releasing factor, LRF luteinizing releasing factor, TRF thyrotrophic releasing factor, and FRF or FSH-RF follicle stimulating hormone releasing factor. However, prolactin $P$ and melanin stimulating factor MSF are inhibited by prolactin inhibitory hormone PIH, and lemanocyte inhibiting hormone, MIF by the hypothalamic secretion.

Hansel (1967) reported the hypothalamus receives information from the external environment via the brain and translates this information into chemical messengers (neurohormones). These messengers or releasing factors are conveyed over the hypophyseal portal system to the adenohypophysis 
where they accelerate or suppress the output of hormones. 1. $\quad \mathrm{STH}-\mathrm{RF}$

The somatotrophic releasing factors are reviewed by Schally, Arimura, and Kastin (1973). Somatotrophic hormone (STH) is released by neuropharmacologic means, and by the demonstration that electrical stimulation of the median eminence induces an increase in the concentration of STH in the plasma of rats. Thus, impulses reaching the hypothalamus may provoke a discharge of STH-RF which in turn stimulates STH secretion from the pituitary. The pituitary stalk pathway of transmission of stimuli is evident as transection abolishes the stimulating effect of hypoglycemia in the release of STH in man.

2. $\mathrm{LH}, \mathrm{FSH}-\mathrm{RF}$

The luteinizing hormone $(\mathrm{LH})$ and follicle stimulating hormone (FSH) releasing factors in rats cause LH and FSH to be stimulated in the hypophysis and secreted. This stimulates spermatogenesis in males and follicular maturation and ovulation in females. In turn the sex hormones progesterone, estrogen, and testosterone secreted by the gonads exert an inhibitory feed-back action on the hypothalamus and the pituitary.

3. $\mathrm{CRF}$

ACTH mediated by the central nervous system from environmentally induced stress can result in the liberation of 
corticotropin releasing factor (CRF) which stimulates the release of ACTH from the pituitary. ACTH augments the secretion of the adrenal cortex of steroids needed for survival. CRF may be useful in diagnostic tests of pituitary function.

4. TRF

Thyroid stimulating hormone (TSH) secreted by the pituitary is regulated by an interaction between hypothalamic thyrotropin releasing factor (TRF) which stimulates TSH release and thyroid hormones $T H$ which inhibits its release. In vitro even picograms of TRF releases TSH from pituitaries in rats with pituitary transplants. Hypophysectomized rats also secrete TSH with the administration of TRF.

$\underline{E}$. Biologic Activity of Pituitary Trophic Hormones and Hypophysectomy

1. STH

Scow, Wagner, and Ronov (1958) reported that STH is a protein anabolic hormone which produces a positive nitrogen balance and, in fasting animals, the level of blood amino acids is lowered. This anabolic effect is facilitated by normal amounts of insulin, cortisone, cortisol, and thyroxine acting in conjunction with it to stimulate the metabolism of fats and carbohydrates. It is assayed by its ability to stimulate cartilage growth in 
hypophysectomized rats. It causes increased nitrogen retention and facilitates the movement of amino acids into cells. Hypophysectomy attenuates growth; administration of STH restores growth.

2 .

Prolactin

Bern and Nicoll (1969) reported a large number of functions attributed to prolactin. Prolactin elicits lactation in rats. However, it promotes growth as STH. It stimulates the corpus luteum and synergistically with progesterone and estrogen stimulates mammary gland growth and development as well as the production of milk. Also, sinergistically with androgens it promotes male accessory growth causing hair maturation as well as sebaceous gland development and activity. Prolactin may produce hyperglycemia, deposition of lipids, and erythropoiesis in rats. 3. FSH

Cole (1964) reported that FSH activity which is influenced by $\mathrm{LH}$, causes an increase in ovarian weight and the stimulation of ovarian follicles in females and in males an increase in testicular weight without stimulation of accessory sex organs in hypophysectomized rats.

FSH stimulates young ovarian follicles to develop multiple layers of granulosa and to form the antra. FSH acting without $\mathrm{LH}$ in hypophysectomized rats does not produce mature ovarian follicles nor do the follicles secrete 
estrogens. The vagina, uterus, and oviducts remain infantile. However, FSH acting alone in hypophysectomized rats stimulates seminiferous tubules but does not activate Leydig cells. Therefore, the male accessories remain atrophic. Therefore, FSH probably has only a gametogenic effect in the absence of $\mathrm{LH}$. 4. LH

Foreman (1963) reported that bioassay of LH is measured by intravenous infusion in rats made pseudopregnant by treatment with mare estrogens followed by a decrease in ascorbic acid in the ovary. FSH has no effect on the ascorbic acid in the luteinized ovary.

LH administered to hypophysectomized rats repairs involuted interstitial cells of the ovary but has no effect on the uterus or vagina. This is interpreted to mean that the ovaries do not secrete estrogens in hypophysectomized rats.

FSH and LH act synergistically to promote estrogensecretion by follicles undergoing maturation and, also, cause ovulation. Moreover, LH serves in the formation of the corpora lutea in rats and, together with prolactin, stimulates the production of progesterone and estrogens by the corpora lutea.

LH activiates the interstitial cells of the testis with the consequent production of androgens (testosterone). 
LH has the same extratesticular effects as the administration of testosterone.

Eik-Nes (1964) reported that the testis of hypophysectomized rats do not produce spermatozoa and the Leydig cells do not secrete enough androgens to maintain accessory sex organs. It is proposed that LH stimulates interstitial cells of Leydig to produce androgens which induce sperm maturation while FSH promotes spermatogenesis.

5 .

$\mathrm{ACTH}$

Lostroh and Woodward (1958) have shown that ACTH production is diminished in hypophysectomized rats and the adrenal cortex becomes atrophic. ACTH administration causes a loss of ascorbic acid from the adrenal cortex. This is useful in bioassay of ACTH function. There is a reappearance of lipids in the adrenal cortex after ACTH is administered to hypophysectomized rats. ACTH levels increase the titers of adreno-cortical steroids in the adrenal venous blood.

White and Engel (1959) showed in vitro that ACTH causes a lipolytic effect directly upon epididimal fat from rat as there was an increase in non-esterified fatty acids in the medium.

6. MSH

Chavin (1959) reported that MSH stimulates melanin synthesis in melanocytes of the epidermis as can be observed in individual cells. The melanin pigment is produced from 
the amino acid tyrosine by the enzyme tyrosinase found in melanocytes. Melanocytes contain dendrites which deposit melanin pigment into adjacent keratinocytes. In hypophysectomy there is a loss of melanin formation in the epidermal melanocytes. Also, the hypothalamus secretes an inhibitor of MSH which supresses its secretion.

7. TSH

Thyroxine is produced in the epithelial cells when stimulated by TSH. First the amino acid tyrosine is iodinated by $\mathrm{I}_{2}$ after oxidation of inorganic iodine by the epithelial cells to form monoiodotyrosine and then diiodotyrosine. Two molecules of diiodotyrosine form thyroxine. Triiodothyronine may be formed by coupling of monoiodotyrosine and diiodotyrosine (Nadler and Young, 1964).

Pitt-Rivers (1961) reported that the liberated thyroglobulins accumulate in the thyroid follicles as storage molecules and are accompanied by proteases also secreted by the epithelial cells. The proteases split thyroglobulins into thyroxine and triiodothyronine. These pass from the follicles into the venous circulation of the thyroid gland and into the systemic circulation.

The functions of the thyroid hormone are metabolic and growth promoting. Basal metabolic rate (BMR) falls after thyroidectomy or hypophysectomy. Heat production falls more in hypophysectomy than in thyroidectomy in the 
rat. Thyroxine and triiodothyronine elevate the BMR in hypophysectomized and throidectomized rats.

8. ADH, Oxytocin

The neurohypophysis stores oxytocin, arginine, vasopressin, and lysine vasopressin in mammals. Vasopressin conserves water and it is called the antidiuretic hormone (ADH). It acts upon the cells of the distal convoluted tubules and collecting ducts of the kidney and causes reabsorption of water by increasing the cells permeability to water.

Sokol and Valtin (1965) reported hypothalamic lesions which destroy the hypophyseal tracts resulted in large water loss through the kidney because of absence of $A D H$. This is known as diabetes insipidus.

Turner and Bagnara (1971) reported that oxytocin promotes uterine contractility to facilitate the ascent of spermatozoa in the female tract and that it aids in expelling the fetus from the female tract at parturition; also, oxytocin stimulates milk ejection. This is a neurohormonal effect initiated by suckling action on the mammary gland nipple. The oxytocin liberated by the neurohypophysis causes contraction of the myoepithelial cells around the mammary gland alveoli.

F. Endocrine Organ Ablation

1. Thyroidectomy

Turner and Bagnara (1971) reported that thyroidectomy 
like hypophysectomy causes a decline in ACTH production. Thyroxine restores the functional capacity of the adrenal cortex but also promotes the release of STH in thyroidectomized rats.

Leathem (1953) reported the reduction in growth rate of thyroidectomized rats parallels the decline in BMR of hypophysectomized rats. Hypophysectomized rats stop growing almost immediately while thyroidectomized rats grow only at a reduced rate. Furthermore, thyroidectomized rats and hypothyroid rats retain sodium and water; the liver and the kidney lose protein and atrophy while serum protein rises.

Scow (1955) has shown that thyroxine has an anabolic effect upon hypophysectomized rats and the growth of all tissues may be stimulated. However, only physiologic doses accomplish this by increasing the protein content of the rat pelt including hair. Excess thyroxine does not stimulate growth. Thyroxine accelerates glucose absorption in the intestines. Liver glycogen stores are depleted as a consequence of liver glycogenolysis and the blood sugar rises.

2. Adrenalectomy, Bilateral

Turner and Bagnara (1971) reported that the adrenal cortex produces cortisol, cortisone, corticosterone, 18 hydroxycorticosterone and aldosterone. The removal of the 
cortex of the adrenal gland causes effects similar to hypophysectomy. There are decreased glucose absorption, depletion of liver glycoger, low blood glucose, and muscle glycogen loss. In addition, adrenalectomized rats excrete less nitrogen during fasting which suggests a decrease in the rate of glucose formation from protein by gluconeogenesis. Iike the hypophysectomized rat, the adrenalectomized animal uses carbohydrate at an accelerated rate. Also, like hypophysectomy, adrenalectomy alleviates the symptoms of pancreatic diabetes. Therefore, there appears to be an increased glucose oxidation and a decrease in gluconeogenesis from protein.

Aldosterone functions in the regulation of electrolytes and water metabolism. Hypophysectomized animals survive without serious impairment of electrolyte balance, whereas adrenalectomized animals die. In hypophysectomized animals the stratum granulosum of the adrenal cortex where aldosterone is produced is preserved but there is atrophy of the stratum fasciculata and reticularis. Sodium loading of rat decreases aldosterone production while sodium depletion increases it. Winternitz, Kintzis, and Long (1957) reported that adrenal glucocorticoid, cortisone and cortisol privation act similarly as hypophysectomy by causing a severe depletion of liver glycogen, low blood glucose, and decreased intestinal absorption of glucose. There is a 
decrease in gluconeogenesis. The accelerated utilization of glucose, failure of both gluconeogenesis and glucose absorption in the intestine causes the rat to become insulin sensitive.

Greengard, Weber, and Singhal (1965) reported that the glucocorticoids (1l oxygenated corticoids) cause a rise in blood sugar, increase in liver glycogen and total body carbohydrate. The increased glycogen store is due to diminished oxidation of glucose and accelerated gluconeogenesis with consequent increase in urinary nitrogen. The glucocorticoids inhibit the phosphorylation of glucose to glucose 6-phosphate by hexokinase step in glucose metabolism in the cell. This may act by potentiating the inhibitory effect of $\mathrm{STH}$ on the hexokinase reaction.

Insulin antagonizes both gluconeogenesis and diminished utilization of glucose. Steiner and King (1964) showed a glycogen increase in the liver of alloxan diabetic rats after injection with insulin; after 24 hours there is an increase in glucose 6-phosphate dehydrogenase activity as well as marked DNA synthesis.

The glucocorticoids may inhibit protein synthesis or increase protein degradation. Cortisone and cortisol may reduce protein synthesis by antagonizing insulin and reducing energy production provided by glucose metabolism.

Also, it is possible that cortical hormones may 
retard protein synthesis by an effect on the metabolism of nucleic acids. Administration of cortical steroids and ACTH to adrenalectomized rats lead to rapid liberation of nitrogen from the spleen, thymus, lymph nodes and liver.

The adrenal medulla is composed of chromaffin cells and postganglionic adrenergic nerves. The adrenal medulla secretes epinephrine and norepinephrine. Iverson (1967) reported that the norepinephrine source is the sympathetic neurons while the epinephrine is secreted by the chromaffin cells of the adrenal medulla.

Turner and Bagnara (1971) reported hypophysectomy causes atrophy of the adrenal cortex but has no effect upon the medulla. Therefore, epinephrine and norepinephrine continue to be secreted. Goldfein and zileli (1958) reported that epinephrine actively causes glycogenolysis in cells raising the blood level of glucose and making it available for metabolism. There is a close relation between elevated glycogen levels and DNA synthesis in cells. Any induced decrease in DNA synthesis in cells causes a decrease in $3 \mathrm{H}$ Tdr into DNA.

\section{Gonadectomy}

Hawkins (1957) has shown that the androgenic hormones produced by the Leydig cells, testosterone and androsterone, can increase the size of muscle, increase the weight of the prostate gland and seminal vesicles of castrated rats. 
Williams and Reddi (1971) have shown that androgens act by feedback upon the pituitary to inhibit the release of gonadotropins. Furthermore, andorgens are necessary for differentiation of the male accessory and secondary sex characters. Also, spermatogenesis, prostate development and secretion are controlled by androgens. In addition, androgens serve to close epiphyseal plates following pubertal growth in bone length.

Turner and Bagnara (1971) reported that the most profound anabolic effect of androgens is in promotion of protein anabolism. They decrease urinary loss of nitrogen and produce increase in body weight. Furthermore, testosterone increases gonadal weight in hypophysectomized rats consequent upon protein retention while castration results in decrease in muscle mass and increase urinary nitrogen excretion. Androgens may support the function of seminiferous tubules and maintain secondary male sex characteristics.

It is proposed by Liao and Williams-Achman (1962) that androgens affect the genome of the target tissues such as muscle, bone, seminal vesicles, spermatozoa, and the prostate leading to production of messenger ribose nucleic acids (RNA). Kochakian (1969) has shown that this in turn facilitates protein synthesis and in laboratory animals testosterone increases protein, RNA and DNA content of the 
prostate gland and seminal vesicles.

G. Effects of Hypophysectomy on Oral Epithelium in Mice

The complex activity of the pituitary hormones acting upon the adrenal cortex, thyroid gland, ovaries and testes, and the release of their respective hormones has not been studied relative to the generation and maturation of oral epithelium in rats. However, because of the clear morphologic and functional changes which occur in other target organs following hypophysectomy, it is reasonable to expect metabolic and developmental effects in the oral epithelium of rats.

In the hypophysectomized or adrenalectomized mice, Dickler, Toto, and Gargiulo (1967) showed a significant delay in the DNA labeling index of the gingiva (Table II). Also, there was evidence of delay in the cell doubling time. Bachnik, Toto, and Gargiulo (1967) also reported a significant delay in DNA synthesis in the gingiva of ovariectomized mice.

H. Hormone Control of Nucleoprotein Metabolism

The effect of hormones within the cell may be mediated by the cell membrane to which the hormone is received and attached; the hormone activates the adenyl cyclase which produces cyclic adenosine monophosphate (AMP). The AMP is known to activate the cell to produce special molecules to increase metabolic activity. 


\section{TABLE II}

ADRENALECTOMIZED MICE AND HYPOPHYSECTOMIZED MICE PERCENTAGE OF LABELED CELLS IN EPITHELIUM OF INTERDENTAL

PAPILLA SECTIONS AT VARIOUS TIME INTERVALS

\begin{tabular}{|c|c|c|c|c|c|}
\hline \multicolumn{2}{|c|}{ Time } & $\begin{array}{l}\text { Adrenalec- } \\
\text { tomized }\end{array}$ & $\begin{array}{c}\text { Hypophy- } \\
\text { sectomized }\end{array}$ & $\begin{array}{l}\text { Ovariec- } \\
\text { tomized* }\end{array}$ & Norma $1 * *$ \\
\hline $1 / 2$ & hour & $7.2 \%$ & $4.8 \%$ & $5.0 \%$ & $6.0 \%$ \\
\hline & hour & 5.28 & $4.7 \%$ & 4.68 & $6.0 \%$ \\
\hline 2 & hour & 5.68 & $6.3 \%$ & 2.98 & $9.0 \%$ \\
\hline 4 & hour & $7.8 \%$ & $5.8 \%$ & $6.5 \%$ & 10.58 \\
\hline 6 & hour & $7.2 \%$ & 3.78 & $6.5 \%$ & $9.0 \%$ \\
\hline 8 & hour & 0.38 & - & $5.4 \%$ & $10.0 \%$ \\
\hline 10 & hour & $9.2 \%$ & $9.5 \%$ & $8.1 \%$ & $15.0 \%$ \\
\hline 12 & hour & $8.5 \%$ & $6.4 \%$ & $6.0 \%$ & $4.0 \%$ \\
\hline 14 & hour & $8.2 \%$ & $9.7 \%$ & $11.0 \%$ & 14.58 \\
\hline 16 & hour & $10.4 \%$ & $11.2 \%$ & $10.5 \%$ & - \\
\hline 18 & hour & $10.5 \%$ & $9.4 \%$ & $11.5 \%$ & $15.0 \%$ \\
\hline 20 & hour & 19.48 & 10.28 & $11.1 \%$ & $10.0 \%$ \\
\hline 22 & hour & $11.6 \%$ & $9.7 \%$ & 7.38 & 15.08 \\
\hline 24 & hour & 12.28 & $12.1 \%$ & 7.08 & $9.0 \%$ \\
\hline 26 & hour & - & - & - & 10.48 \\
\hline 28 & hour & $9.3 \%$ & $13.2 \%$ & $6.8 \%$ & - \\
\hline 32 & hour & $6.5 \%$ & $10.2 \%$ & $7.2 \%$ & $10.0 \%$ \\
\hline 36 & hour & 7.98 & $9.7 \%$ & $6.8 \%$ & $5.0 \%$ \\
\hline 40 & hour & $13.6 \%$ & $7.1 \%$ & $8.1 \%$ & - \\
\hline 44 & hour & 13.08 & $19.1 \%$ & $6.4 \%$ & $6.0 \%$ \\
\hline 48 & hour & - & $11.6 \%$ & $6.7 \%$ & $5.0 \%$ \\
\hline 3 & days & $5.3 \%$ & $10.3 \%$ & $4.4 \%$ & $4.0 \%$ \\
\hline 4 & days & $7.5 \%$ & $7.4 \%$ & $2.1 \%$ & $8.0 \%$ \\
\hline 5 & days & 6.18 & $6.7 \%$ & $2.9 \%$ & $1.7 \%$ \\
\hline
\end{tabular}

*Bachnik, 1966.
**Joglekar, 1964.

Reproduced from Dickler, E., Toto, P.D., Gargiulo, A.W.: Cell Kinetics of the Oral Epithelium of Adrenalectomized and Hypophysectomized Mice, Perio. 5:467-469, 1967. 
Davidson (1968) reported that estrogen administered to ovariectomized animals stimulates the uterus to produce protein as measured by radioactive amino acid uptake or measuring protein production of homogenized uterus tissue in vitro. Protein production in the uterus is preceded by the synthesis of RNA after estrogen administration. Therefore, it is concluded that estrogens stimulate RNA synthesis by the nuclear DNA. The uterus produces amino acids from glucose metabolism, evolves carbon dioxide and increases the synthesis of fat and phospholipid. Also, there is evidence of increased ribosomal RNA in the uterus endometrium following estrogen administration. This is supported by evidence of increased synthesis of the DNA-RNA polymerase enzyme needed to transcribe all RNA.

Testosterone has been shown to increase RNA synthesis in the liver of castrate male and female rats.

Davidson (1968) also reported that in the adrenalectomized animal cortisone stimulates protein synthesis in the liver including enzymes needed to produce glucose from protein by gluconeogenesis. This occurs by cortisone inducing the production of ribosomal and messenger RNA. Also, cortisone causes glycogenesis by inducing phosphorylase synthesis. Moreover, cortisone stimulates protein synthesis by RNA in the liver.

Edelman, Bogoroch, and Porter (1964) reported that 
aldosterone, radioactively labeled, enters the nucleus of cells lining the bladder of toads. This is followed by an increased movement of sodium ions across the plasma membrane. Kidson, Kirby, and Beatty (1964) have shown that rats separately injected with cortisone, thyroxine, testosterone, and insulin showed increased RNA synthesis in the liver. They showed that such hormones activate the genes in liver cells.

O'Malley and Schrader (1976) reported that estradiol labeled with tritium is concentrated in the nuclei of uterine endometrium including the squamous epithelium of the cervix. They reported that such cells have specific receptor nuclear proteins intimately associated with the DNA. They stated that stradiol activates the genes after being bound to receptor proteins. This is evidence that steroid hormones reach the nucleus and activate the genes in squamous cells of the uterus.

DNA synthesis is a basic biologic phenomenon required in any growth in rats. The level of the activity may be measured by labeling with Tar to assess the frequency of labeling. This study proposes to count differentially the nuclei of tritiated thymidine labeled cells of the palate in hypophysectomized rats. 
CHAPTER III

MATERIAL AND METHODS

A. Weight

Twenty young adult female albino rats, 45 days of age, weighing approximately 60 grams were divided into two groups of ten each. One group of ten was hypophysectomized.* They were kept in cages and fed Lab Lox Chow and water ad libitum for a period of five days. Tritiated thymidine specific activity (1.8 $\mathrm{Ci} \mathrm{mM})$ was administered intraperitoneally at a rate of $0.7 \mu \mathrm{Ci}$ per gram of animal weight. All of the animals were sacrificed one hour later.

B. Autoradiography

A section of palatal mucosa approximately $.4 \mathrm{x} .5 \mathrm{~cm}$ was removed at midline from each rat, fixed in $10 \%$ formaline for eight hours, dehydrated in ascending alcohols $65 \%, 70 \%$, 80\%, 90\%, 95\%, transferred to xylene and then embedded in paraffin. Sections, $6 \mu$ thick, were cut by microtome and placed on glass slides. In the dark room the slides were dipped in liquid emulsion NTB $3 * *$, placed in light-tight

*Hormone Assay Company, Chicago, Illinois.

**New England Nuclear, Boston, Massachusetts. 
boxes and placed in a freezer $\left(0^{\circ} \mathrm{C}\right)$ for ten days. They were developed, washed and fixed to produce an autoradiogram and stained with Nuclear Fast Red and Indigo Carmin.

C. Cell Density

Ten sections from experimental and ten from control rat palatal mucosa were examined with a binocular light microscope with a $100 \mu^{2}$ grid in one eyepiece. Twenty-five fields of $100 \mu^{2}$ were surveyed and on each section the number of nuclei were counted. The number of nuclei per $100 \mu^{2}$ was calculated to determine cell density/100 $\mu^{2}$.

D. Labeling Index

Ten sections from each control and experimental palatal specimen were surveyed using the eyepiece grid as a guide and a record of all of the labeled and non-labeled nuclei in all layers of the stratified squamous epithelium were counted. Fifty thousand counted nuclei served as the limit of total cell count in the experimental and the control rat epithelia. A ratio of the labeled to non-labeled cell counts was then calculated and an index of this number of labeled cells per 1000 cells served as the labeling index. The numbers of labeled cells in the ten experimental and ten control mucosal specimens were summed and the mean and the standard deviation were determined. The means of labeled cells were compared by employing the " $t$ " test to determing any significance. 
E. Thickness

The thickness of the palatal oral epithelium in the control and hypophysectomized rats was measured with the aid of a calibrating slide* ( $2 \mathrm{~mm}$ line) and a reticular eyepiece* $\left(100 \mu^{2}\right)$ on the microscope*, at a magnification of 100x. Ten sections each of control and experimental rats were examined with the reticular eyepiece; $100 \mu$ calibrating lines on the eyepiece was equal to 0.01 millimeters. The selected sections were measured at areas of the epithelium showing flat ridges in order to avoid variations imposed by oblique sections through the elongated epithelial ridges which could give apparently greater values of thickness.

*American Optical Co., Rochester, New York. 
CHAPTER IV

RESULTS

A. Weight

The 50-day-old control rats significantly gained weight during the period of five days while the hypophysectomized animals significantly failed to gain weight. At the beginning of the experiment the control rats averaged 60.1 grams and after five days 69.1 grams. The hypophysectomized rats weighed 59.2 grams at the beginning and 60.1 grams five days later (Table III-1).

B. Epithelial Morphology

The oral mucosa both of the control and hypophysectomized rats showed a similar pattern. The basal cells normally are related to the basement membrane and contain small nuclei. There is a normal pattern of differentiation in the differentiating spinous layer with an increase in nuclear and cytoplasm size as the cells enlarge. The intercellular bridges appear essentially similar in the epithelia of both control and of experimental animals. There is a well differentiated stratum corneum showing the absence of nuclei: orthokeratinization. The lamina propria is composed of fibrocytes, dense collagenous fiber bundles, and contains patent capillaries (Figures 1 and 2 ). 
TABLE III-I

WEIGHTS OF CONTROL AND HYPOPHYSECTOMIZED RATS 50-DAYS-OLD

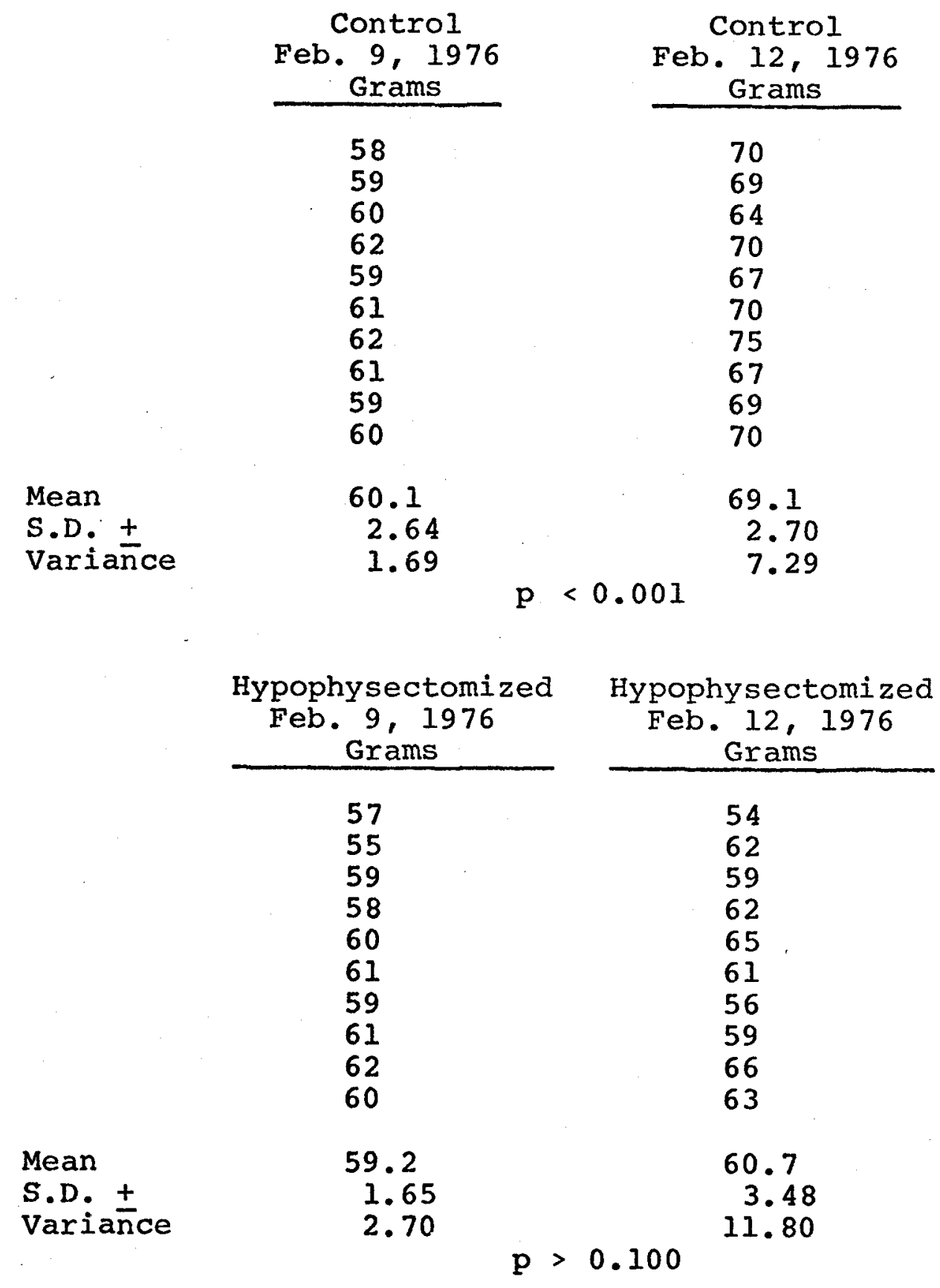




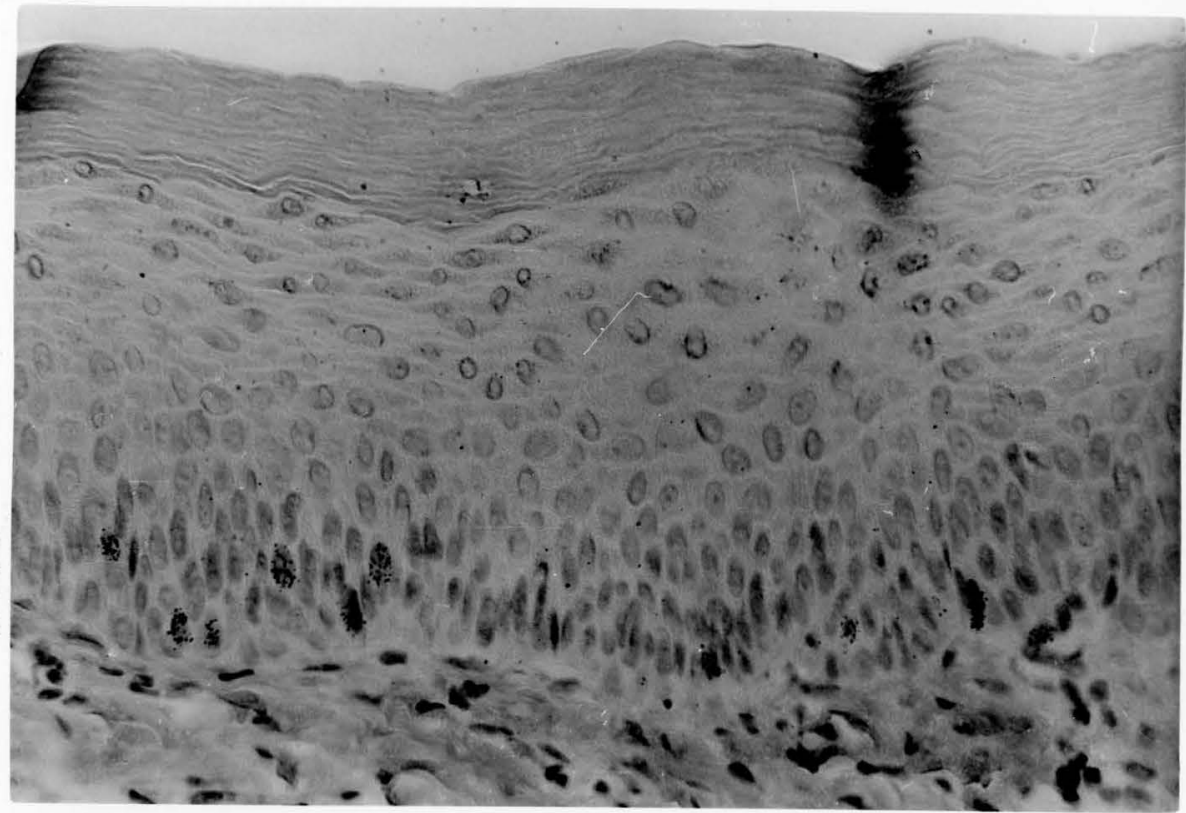

FIGURE 1

NORMAL RAT PALATAL MUCOSA

Palatal epithelium in 50-day-old rat averages $0.603 \mathrm{~mm}$ in thickness, shows a cell density of $176 \mathrm{cells} /$ $100 \mu^{2}$ and a labeling index of 48 cells/1000 cells. The morphology is normal showing basal, spinous, stratum granulosum and stratum corneum. Autoradiogram, Nuclear Fast Red and Indigo Carmin. 100x. 


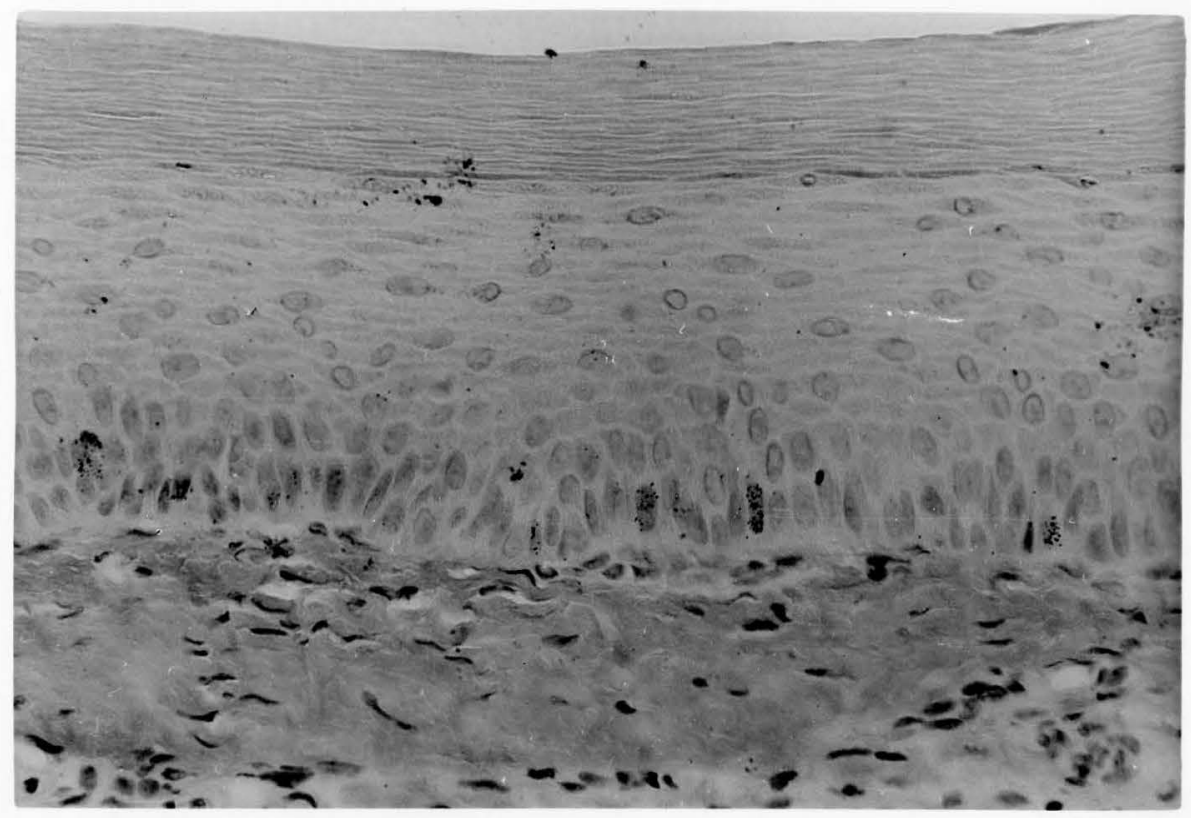

FIGURE 2

HYPOPHYSECTOMIZED RAT PALATAL MUCOSA

Palatal epithelium in 50-day-old rat hypophysectomized for five days averages $0.350 \mathrm{~mm}$, shows a cell density of 124 cells $/ 100 \mu 2$ and a labeling index of 24 cells/1000 cells. The morphology shows a normal differentiation pattern as the normal epithelium. Note reduced labeling of basal cells, wider spacing of cells in the stratum spinosum and evident reduced thickness compared to normal. Autoradiogram, Nuclear Fast Red and Indigo Carmin. 100x. 
c.

Epithelial Thickness

There is a reduction in the thickness of the palatal epithelium in hypophysectomized rats as compared to the controls. The thickness of the palatal epithelium varied between $0.25 \mathrm{~mm}$ and $0.45 \mathrm{~mm}$ in the hypophysectomized rats and $0.46 \mathrm{~mm}$ and $0.74 \mathrm{~mm}$ in the control rats with a significant difference in the means of $0.310 \mathrm{~mm}$ and $0.603 \mathrm{~mm}$, respectively (Table III-2).

D. Cell Density

There was a significant decrease in the cell density of the oral epithelium in hypophysectomized rats.

The number of nuclei counted in the oral epithelium of control and hypophysectomized rats as determined with the guide of a $100 \mu^{2}$ reticular in the eyepiece of the microscope showed that there were $176 / 100 \mu^{2}$ in the control and $124 / 100 \mu^{2}$ in the hypophysectomized rats (Table III-3). E. Labeling Index

The cell density revealed that there was an average of $176 / 100 \mu^{2}$ in the control animals which required the counting of six fields to survey 1000 cells and 300 fields to survey 50,000 cells. As there were 10 control specimens, 30 fields $100 \mu^{2}$ were surveyed from representative autoradiographic sections of the control rats. This revealed a frequency of tritiated thymidine labeled cells to be $48 / 1000$. similarly, the cell density of the squamous epithelium 
TABLE III-2

THICKNESS OF PALATAL SQUAMOUS EPITHELIUM IN 50-DAY-OLD FEMALE RATS

5 DAYS FOLLOWING HYPOPHYSECTOMY

Control Hypophysectomized

$\begin{array}{ll}\mathrm{mm} & \mathrm{mm} \\ .46 & .25 \\ .48 & .30 \\ .50 & .30 \\ .54 & .30 \\ .55 & .35 \\ .60 & .40 \\ .64 & .40 \\ .65 & .40 \\ .66 & .40 \\ .75 & .40\end{array}$

Mean

0.603

S.D. +

1. 3

Variañce

0.068

0.350

0.086

0.050

$p<0.001$ 
TABLE III-3

THE CELL DENSITY OF SQUAMOUS CELLS IN THE PALATE OF CONTROL AND HYFOPHYSECTOMIZED RATS 55-DAYS-OLD

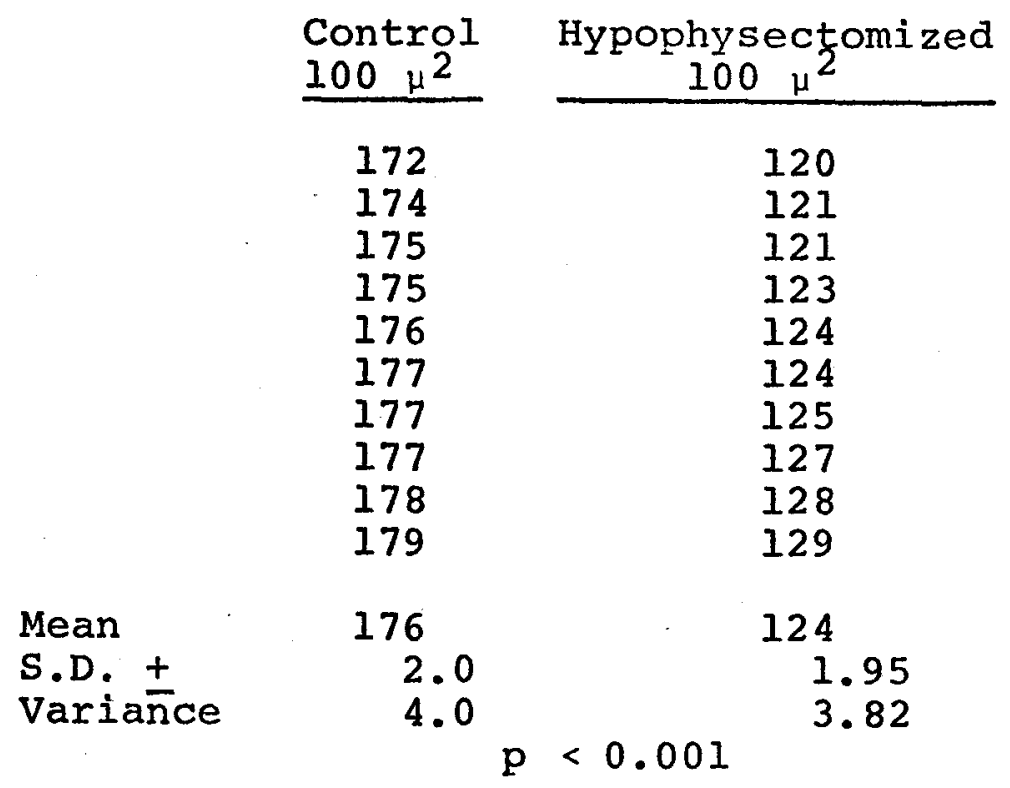


in the hypophysectomized rats was $124 / 100 \mu^{2}$ which required the counting of eight fields to survey 1000 cells and 400 fields for 50,000 cells. Accordingly, 40 fields in each of the autoradiographic sections from the ten representative specimens of palatal epithelium were surveyed. This revealed a labeling index of $24 / 1000$ (Table III-4). There was a significant difference in the labeling index of the sugmous epithelium of the palate between normal and hypophysectomized female rats, $48 / 100 \mu^{2}$ and $24 / 100 \mu^{2}$, respectively (Table III-4). 
TABLE III-4

TRITIATED THYMIDINE LABELING FREQUENCY OF THE PALATAL SQUAMOUS EPITHEIIUM IN CONTROL AND HYPOPHYSECTOMIZED RATS 55-DAYS-OLD

Labeled Cells/1000

Control Hypophysectomized

$\begin{array}{ll}41 & 20 \\ 46 & 21 \\ 46 & 22 \\ 47 & 23 \\ 48 & 24 \\ 49 & 25 \\ 49 & 25 \\ 49 & 26 \\ 52 & 27 \\ 53 & 27\end{array}$

Mean

S.D. \pm

48

Variañce

3.17

24

10.0

2.9

$p<0.001$

8.3 


\section{CHAPTER V}

\section{DISCUSSION}

A. Weight

Female rats 50 -days-old fail to gain weight over a period of five days following hypophysectomy. Weight loss in hypophysectomized rats has been reported by scow, Wagner, and Ronow (1958). Rats fifty-days-old are growing and, at the same time, they are renewing the oral epithelium. Therefore, hypophysectomy reduces at least the growth fraction of oral squamous cells and probably the renewal fraction as we11.

B. Epithelial Morphology

The stratified squamous epithelia in both hypophysectomized and control albino rats show normal morphologic characteristics. This suggests that hypophysectomy of fifty-day-old rats does not alter the pattern of differentiation and maturation. The pattern of differentiation from basal layer through the spinous layer and stratum corneum is normal.

C. Epithelial Thickness

There is a significant reduction in the epithelial thickness in the palate of hypophysectomized rats. This may be explained by the failure of the oral epithelium to 
grow as a part of the general weight loss seen in the rats. of course, a reduction in the renewal of cells by a depression in DNA synthesis undoubtedly contributes both to a reduction in growth as well as the rate of cell renewal. The epithelium of the normal 50-day-old rat is $0.603 \mathrm{~mm}$ which is less than $1.33 \mathrm{~mm}$ as reported by Gerson and Meyer (1964) in adult rats. However, this may be explained by the fact that the growing 50-day-old rat has not yet achieved full adult growth of oral epithelium. The loss of gonadotropic hormones in LH and FSH are known to result in the failure of maturation of the ovum and the failure of corpus luteum formation leading to a depression in estogen and progesterone in rats. This leads to a thin infantile vaginal squamous epithelium. However, in fifty-day-old female rats the maturation of the ovum does not occur. Therefore, such lack of estrogens probably does not contribute to the reduction of oral epithelium thickness. Of course, constant loss of superficial cells ultimately contributes to the total loss of the squamous cells if the epithelium fails to reproduce new cells.

D. Cell Density

The hypophysectomized rats show a reduced cell density. The smaller numbers of cells per $100 \mu^{2}$ may represent the consequence of reduced new cell formation. In particular, a reduction in the number of cells may be accompanied 
by an increase in the cell size. This could be a compensatory mechanism allowing the reduced number of cells to cover the surface area of the oral mucosa. Such enlargement of the squamous cells also may represent the increase in cytoplasmic volume due to the increase in time. Such squamous cells remain longer in situ. It is well known that as squamous cells migrate from the basal layer through the spinous layers they increase in diameter. Such changes in size allow for each cell to cover a wider surface of the oral mucosa as ultimately they flatten on the surface. Such loss in cell density has been observed in old rats and also interpreted as a cell enlargement due to retention and continued maturation by Toto, Rubinstein, and Gargiulo (1975). This suggests that hypophysectomy allows mature cells to continue their maturation in situ. E. Labeling Index

There is a reduction in the frequency of cells in DNA synthesis in hypophysectomized rats. This failure in DNA synthesis explains both a reduction of growth, cell renewal, and epithelial thickness. The synthesis phase of the cell cycle requires about 8 - 10 hours in the oral epithelium. It would be significant to learn what is the generation cycle time and to determine if the synthesis phase time is increased. Aging mice show an increased time required for the synthesis phase of oral epithelium from $10-12$ hours as 
reported by Barakat, Toto, and Choukas (1969). A reduction in the labeling index of the gingival epithelium also was reported in hypophysectomized mice by Dickler, Toto, and Gargiulo (1967) .

The requirements for DNA synthesis include essential energy provided by ATP. ATP is depressed in hypophysectomized rats. This effect is thought to result from the hypoglycemic effect of hypophysectomy as glucose is the principal metabolite essential for the synthesis of ATP.

The protein synthesis in squamous cells also may be inhibited as STH privation causes a failure of amino acid retention in tissues. Any depression in the enzymes synthesized in squamous cells needed for DNA synthesis, glycogen, and keratin synthesis can be expected to depress DNA synthesis resulting in a reduced tritiated thymidine labeling frequency as seen in this study. Bullough (1961) reported that glucose availability to epidermal cells controls the length of the cell cycle.

Insulin activity is inhibited by STH and glucocorticoids normally. However, in hypophysectomized animals, insulin contributes to glucose utilization and no doubt is responsible for the growth level and renewal of the oral epithelium as observed in the palate of hypophysectomized rats.

A depression of thyroxine synthesis because of a loss of TSH also contributes to a reduction in the rate of glucose 
absorption from intestines and metabolism. This further contributes to the failure of general growth and probably growth in the oral epithelium as well.

The adrenal medulla is intact in hypophysectomized animals and can be expected to synthesize and secrete epinephrine and norepinephrine. As epinephrine causes glycogenolysis in cells it contributes to elevated blood glucose as reported by $\mathrm{zileli}$ (1958). Such elevated blood glucose could contribute to the needs of squamous epithelium for DNA synthesis provided epinephrine does not cause glycogenolysis and loss of glucose in such cells. Moreover, Bullough indicates that epinephrine complexed with chalones inhibits mitosis. Therefore, epinephrine levels in hypophysectomized rats may serve to depress DNA synthesis in oral epithelium. The glycogenolysis in the liver produced by epinephrine may provide the glucose needed by the squamous epithelial cells for DNA synthesis.

While there is evident and significant depression of DNA synthesis in the oral epithelium of the hypophysectomized rat, DNA synthesis still occurs. One might suggest that the lower level of DNA synthesis proceeds with the availability of glucose and insulin in the blood and the glycogenolytic activity in the squamous cells contributing to the basal needs of the squamous cell.

The loss of STH probably has a profound effect on 
the growth fraction of squamous epithelium in hypophysectomized rats. STH stimulates growth by producing a positive nitrogen balance in the rat. This anabolic effect is facilitated by normal amounts of insulin, cortisone, cortisol and thyroxine. While insulin may be available in adequate quantities, cortisone, cortisol and thyroxine are depressed and this may contribute to the failure of growth of the oral epithelium in rats.

The depression in adrenal corticoids following hypophysectomy in rats causes a depression in blood glucose as gluconeogenesis is depressed. Also, there is increased glucose metabolism. The reduction in the glucocorticoids removes the inhibitory effect upon phosphorylation of glucose to glucose- 6 phosphate.

The protein needs of the squamous cells are diminished in hypophysectomized rats. As the glucocorticoids do not produce gluconeogenesis, there is a reduction in glucose and amino acids. But, the hypothyroid state of hypophysectomized rats causes atrophy of the liver with a rise in blood proteins. However, in the absence of STH, blood amino acids are catabolized and excreted by the kidneys reducing their availability to the squamous cells. Androgenic hormones produced by the adrenal cortex are depressed in hypophysectomized rats and would result in a failure of protein anabolism. Furthermore, in 50-day-old female rats, a depression 
of FSH and LH, and the resulting failure of ovum maturation and interstitial cell secretion would lower estrogen levels. Estrogens promote RNA synthesis and protein production in the vaginal squamous epithelial cells while their absence depresses such activity. It is not known if estrogen receptors are in oral squamous epithelium but should they be present, one could suggest that estrogen privation could contribute to low protein metabolism as a contribution to the failure of epithelial growth there as well.

The failure of growth in the oral epithelium of hypophysectomized rats may be caused by reduced availability of estrogens, corticosteroids, thyroxine and also a decrease in RNA synthesis in the epithelial cells, and a diminished protein synthesis. Such a decrease in RNA synthesis is not known to occur in oral squamous epithelium as a result of hypophysectomy. However, this would be an important consideration in determining the cause of growth failure in the epithelium. The function of estrogens, aldosterone, thyroxine, cortisol, and insulin all have been reported to increase RNA synthesis in certain target organs (Davidson, 1968; Edelman, Bogoroch, and Porter, 1964; Kidson, Kirby, and Beatty, 1964; O'Malley and Schrader, 1976). 


\section{CHAPTER VI}

\section{SUMMARY AND CONCLUSIONS}

Ten hypophysectomized and ten normal female albino rats 50-days-old were kept for five days and treated with tritiated thymidine one hour before sacrifice. The animals were weighed, the histomorphology of the palate epithelium was studied including the thickness, cell density, and DNA labeling index. The hypophysectomized rats failed to gain weight after five days. The palatal epithelium showed a normal morphology indicating the hypophysectomy allowed for differentiation of squamous epithelium. There was a significant reduction in the thickness of the epithelium and a reduced cell density. This was attributed to a significant decrease in DNA synthesis. The epithelial cells were lost from the surface without adequate replacement due to an expected depression in mitotic activity. DNA synthesis may be depressed due to reduced ATP synthesis resulting from suboptimal glucose metabolism and depression in protein synthesis. 


\section{CHAPTER VII}

\section{BIBLIOGRAPHY}

Bachnik, F., Toto, P., Gargiulo, A.: Cell Renewal Time and Movement in Ovariectomized Mouse Interdental Epithelium, J. Perio. 5: 172-174, 1967.

Barakat, N.J., Toto, P.D., Choukas, N.C.: Aging Cell Renewal of Oral Epithelium, J. Perio. 41: 599-602, 1969 .

Barrington, E.P., Meyer, J.: Regional Differences in Gradients of Dry Residue Density in Oral Epithelia of the Rat: A Quantitative Study, Arch. Oral Biol. 14: 1085-1099, 1959.

Bern, H.A., Nicoll, C.S.: The Comparative Endocrinology of Prolactin, Rec. Progr. Horm. Res. 24: 681, 1968 .

Bullough, W.S., Lawrence, E.B.: Stress and Adrenaline in Relation to the Diurnal Cycle of Epidermal Mitotic Activity in Adult Male Mice, Proc. Roy. Soc. B. 154: 159 , 1961.

Bullough, W.S., Iawrence, E.B.: Mitotic Control by Internal Secretion: The Role of the Chalone-Adrenaline Complex, Exptl. Cell Res. 33: 176-194, 1964 .

Carlton, A.: Mitosis in Mouse Epidermis, J. Anat. 68: $251,1934$.

Catchpole, H.R., Joseph, N.R., Engel, M.B.: Homeostasis of Connective Tissues. III. Magnesium-Sodium Equilibrium and Interaction with strontium and Iead, Arch. Path. 61: 503-511, 1956.

Chavin, W.: Pituitary Hormones in Melanogenesis, M. Gordon (Ed.), Pigment Cell Biology, New York: Academic Press, 1959 , p. 63. 
Cole, H.H. (Ed.): Gonadotropins, Their Chemical and Biological Properties and Secretory Control, San Francisco: W.H. Freeman and Co., 1964.

Davidson, E.: Hormone and Genes in the Molecular Basis of Life, San Francisco: W.H. Freeman and Co., 1968. pp. 254-263.

Dickler, E., Toto, P.D., Gargiulo, A.W.: Cell Kinetics of the Oral Epithelium of Adrenalectomized and Hypophysectomized Mice, J. Perio. 5: 467-469, 1967.

Eik-Nes, K.B.: Effects of Gonadotropins on Secretion of Steroids by the Testis and Ovary, Physiol. Rev. 44: 609 , 1964 .

Fawcett, D.W.: The Cell, Its Organelles and Inclusions, Exptl. Cell Res. Suppl. 18: 74, 1961.

Foreman, D.: Effects of Gonadotrophic Hormones on the Concentration of Ascorbic Acid of the Rat Ovary, Endocr. 72: 693, 1963.

Gersh, I., Catchpole, H.R.: The Nature of Ground Substance of Connective Tissue, Persp. Biol. Med. 3: 282-319, 1960 .

Goldfein, A., Zileli, M.S., Despointes, R.H., Belhume, J.E.: The Effects of Hypoglycemia on the Adrenal Secretions of Epinephrine and Norepinephrine, Endocr. 62: 749, 1958.

Grandel, E.R., Toto, P.D.: Acid Mucopolisaccharides in the Oral Epithelium, J. Perio. 4: 127-130, 1966.

Grav, H.J., Smellie, M.S.: Incorporation Pathway of Tdr into Squamous Cells, J. Biochem. 94: 518, 1963.

Grav, H.J., Smellie, M.S.: The Incorporation Pathway of Tritiated Thymidine into Squamous Cells, J. Biochem. 89: 486,1964 .

Greengard, O., Weber, G., Singhal, R.L.: Glycogen Deposition in the Liver Induced by Cortisone. Dependence on Enzyme Synthesis, Science 141: 160, 1963. 
Hansel, W.: The Hypothalamic and Pituitary Functions in Mammale, Int. J. Fertil. 6: 241, 1961.

Hanse, E.R.: Mitotic Activity and Mitotic Duration in Tongue and Gingival Epithelium in Mice Effect of Chalones, Odont. Tidskr. 75: 480-487, 1967.

Harkin, J.C.: An Electron Microscopic Study of Castrations Changes in the Rat Prostate, Endocr. 60: $185,1957$.

Henry, J.L., Meyer, J., Weinmann, J.P., and Schour, I.: Pattern of Mitoses Activity in Oral Epithelium of Rabbits, Arch. Path. 54: 281-297, 1952.

Iverson, I.L.: The Uptake and Storage of Noradrenaline in Sympathetic Nerves, Cambridge, England: Cambridge Univ. Press, 1967.

Joglekar, A., Toto, P.D., Gargiulo, A.W.: Cytological Study of the Migration of the Epithelial Cells of the Mouse Interdental Papillae, J. Perio. 35: $375-380,1964$.

Jones, K.W.: The Role of the Nucleus in the Formation of Ribosomes, J. Ultrastruct. Res. 13: 257-262, 1965.

Joseph, N.R., Engel, M.B., Catchpole, H.R.: Interactions of Ions and Connective Tissue, Biochem. Biophys. Acta 8: $575-587,1952$.

Kidson, C., Kirby, K.S.: Selective Alterations of Mammalian Messenger RNA Synthesis, Evidence for Differential Action of Hormones on Gene Transcription, Sci. Amer. 203: 569-603, 1964.

Kockakian, C.D.: Intracellular Regulations of Nucleic Acids of Mouse Kidney by Androgen, Gen. Comp. Endocr. 13: 146, 1969.

Leathem, J.H.: Relationships Between the Thyroid and Protein Metabolism. In W.H. Cole (Ed.): Protein Metabolism, Hormones and Growth. New Brunswick, N.J.: Rutgers Univ. Press, 1953, p. 17. 
Liao, S.; Williams-Ashman, H.J.: An Effect of Testosterone on Amino Acid Incorporation by Prostate Ribonucleoprotein Particles, Proc. Nat. Acad. Sci. 48: 1956, 1962 .

Lostroh, A.J., Woodward, P.: Changes in the Adrenal of the Hypophysectomized C3H Mouse with L-Corticotropin and Growth Hormone, Endocr. 62: 498, 1958.

Malamud, D., Baserga, R.: Glycogen Concentration and DNA Synthesis, Exptl. Cell Res. 50: 581-588, 1968.

Meyer, J., Medak, M., Weinman, J.P.: Mitotic Activity and Rates of Growth in Regions of Oral Epithelium, Differing in Width, Growth 24: 29-46, 1960.

Meyer, J., Squier, C.A.: Current Concepts of the Histology of Oral Mucosa, Springfield, I11.: Thomas, 1971, pp. 86-88.

Moscona, A.: The Asocialbility of Cells, Proc. Soc. Exptl. Biol. 92: 410, 1956.

Nadler, N.J., Young, B.A., Leblond, C.P., Mitnaker, B.: Elaboration of Thyroglobulin in the Thyroid Follicle, Endocr. 74: 333, 1964.

Ogle, C.: Effect of Environmental Temperature on Body Weight, Amer. J. Physiol. 107: 635, 1934.

O'Malley, B.W., Schrader, W.T.: The Receptors of Steroid Hormones, Sci. Amer. 234: 32-43, 1976.

Palade, G.E., Farquar, M.G.: A Special Fibril, the Dermis, J. Cell. Biol. 27: 215-224, 1965.

Perry, R.P.: The Nucleolus and Synthesis of Ribosomes in Progress in Nucleic Acid, Res. \& Molecular Biol.

6: 219-257, Davidson, J.N., Cohn, W.E. (Ed.), New York: Academic Press, 1967.

Pitt-Rivers, R.: Iodine Metabolism in the Thyroid Gland, Mem. Soc. Endocr. 11: 71, 1961.

Plackova, A., Waterhouse, J.P., Meyer, J.: Glycogen in Clinical Leukoplakia. Distribution and Fine Structures in Human Buccal Mucosa, Arch. Derm. 102: $291-299,1970$. 
Porter, G.A., Bogoroch, R., Edelman, S.: On the Mechanism of Action of Aldosterone in Sodium Transport, The Role of RNA Synthesis, Proc. Nat. Acad. Sci. 52: 1326-1333, 1964.

Prendergrast, R.C., Toto, P.D., Gargiulo, A.W.: Reactivity of Blood Group Substances of Neoplastic Oral Epithelium, J. Dent. Res. 47: 306-310, 1968.

Scow, R.D.: Effect of Thyroxine on the Weight and Composition of Muscle, Pelt and Other Tissues in Young Hypophysectomized Rats, Endocr. 53: 344, 1955.

Schroeder, H.E., Theilade, J.: Electron Microscopy of Normal Human Gingival Epithelium, J. Perio. Res. 1: 95-119, 1966.

Sharav, Y.: Age Changes in Oral Epithelia, M.S. Thesis, University of Illinois, Chicago, Illinois, 1966.

Singer, S.J., Nicolson, G.L.: The Structure of Chemistry of Mammalian Cell Membranes, Amer. J. Path. 65: $427,1971$.

Sokol, H.W., Valtin, H.: Morphology of the Neurosecretory Mechanism in Rats Homozygous and Heterozygous for Hypothalamic Diabetes Insipidus (Brattleboro Shain), Endocr. 77: 692, 1965.

Toto, P.D., Dhawan, A.: Generation Cycle of Oral Epithelium in 400-Day-Old Mice, J. Dent. Res. 45: 948$950,1966$.

Toto, P.D., Ojha, G.: Generation Cycle of Oral Epithelium in Mice, J. Dent. Res. 41: 388-391, 1962 .

Toto, P.D., Rubinstein, A., Gargiulo, A.W.: Labeling Index and Cell Density of Aging Oral Rat Tissues, J. Dent. Res. 54: 555-556, 1975.

Turner, C.D., Bagnara, J.T.: General Endocrinology, Philadelphia: W.B. Saunders Co., 1971, pp. 315, 452-453. 
Waldeyer, W.: Untersuchungen Uber die Histogenese der Horngebilde Insbensondere der Haare und Federn. In Betrage zur Anatomie und Embriologie, Alst Festgabe Jacob Henle, Bonn: Max Cohen \& Sohn, 1882 , pp. 141-163.

Weinmann, J.P., Meyer, J., Mardfin, D., Weiss, M.: Occurrence and Role of Glycogen in the Epithelium of the Alveolar Mucosa and of the Attached Gingiva, Amer. J. Anat. 104: 381-402, 1959.

Weinmann, J.P., Meyer, J., Medak, H.: Correlated Differences in Granular and Keratinous Layers in the oral Mucosa of the Mouse, J. Invest. Derm. 34: 423-431, 1960 .

Weiss, M.D., Weinmann, J.P., Meyer, J.: Degree of Keratinization and Glycogen Content in the Uninflamed and Inflamed Gingiva and Alveolar Mucosa, J. Perio. 30: 208-218, 1959 .

White, G.E., Engel, F.I.: Fat Mobilization by Purified Corticotropin in the Mouse, Proc. Soc. Exptl. Biol. Med. 102: 272, 1959.

Williams-Ashman, H.G., Reddi, A.H.: Androgenic Regulation of Tissue Growth in the Androgens, the Testis, Eik-Nes, K.B. (Ed.), New York: Marcel Dekker, 1970 , p. 117.

Winternitz, W.W., Dintzis, R., Long, C.N.H.: Further Studies on the Adrenal Cortex and Carbohydrate Metabolism, Endocr. 61: 724, 1957.

Wislocki, G., Fawcett, D., Dempsey, F.: Staining of stratified Squamous Epithelium of Mucous Membranes and Skin of Man and Monkey by the Periodic Acid Schiff Method, Anat. Rec. 110: 359-375, 1951. 


\section{APPROVAL SHEET}

The thesis submitted by Olivia Ramirez has been read and approved by the following committee:

Dr. Patrick D. Toto, Director

Professor and Chairman, Oral Pathology, Loyola

Dr. Donald B. Doemling

Associate Professor and Chairman, Physiology and Pharmacology, Loyola

Dr. Anthony W. Gargiulo

Professor and Chairman, Periodontics, Loyola

The final copies have been examined by the director of the thesis and the signature which appears below verifies the fact that any necessary changes have been incorporated and that the thesis is now given final approval by the Committee with reference to content and form.

The thesis is therefore accepted in partial fulfillment of the requirements for the degree of Master of Science.
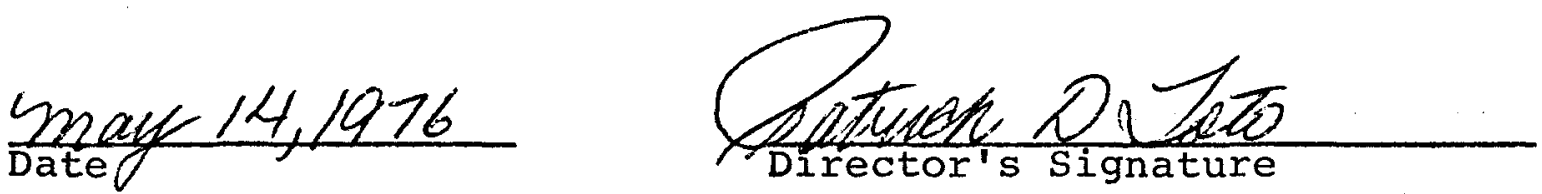